\title{
Focus
}

\section{Op de sabbat, dat is op de rustdag, trouw tot Gods gemeente komen}

\author{
W.H.Th. Moehn
}

\begin{abstract}
Casey B. Carmichael, A Continental View: Johannes Cocceius's Federal Theology of the Sabbath [Reformed Historical Theology 41] (Göttingen: Vandenhoeck \& Ruprecht, 2019), 192 p., €64,99 (ISBN 9783525552780). Kyle J. Dieleman, The Battle for the Sabbath in the Dutch Reformation: Devotion or Desecration? [Reformed Historical Theology 52] (Göttingen: Vandenhoeck \& Ruprecht, 2019), 255 p., €64,99 (ISBN 9783525570609).
\end{abstract}

De titel van dit artikel is een onderdeel van antwoord 103 van de Heidelbergse Catechismus. Een opvallende uitbreiding ten opzichte van het sobere 'sonderlich am feiertag' in de oorspronkelijke Duitse tekst. De uitleg van het vierde gebod (volgens de telling van de decaloog in de gereformeerde traditie) blijft een heet hangijzer. Het is een gebod dat meer hermeneutische vragen en moeilijkheden oproept dan de negen andere woorden van de decaloog. Waarom is dit het enige gebod in de Decaloog dat nergens in het Nieuwe Testament wordt genoemd en ook niet letterlijk in acht is genomen in de vroege kerk? Wat is het eigene van de zondag, zodat deze dag meer is dan een verplaatste sabbat? Zouden christenen er goed aan doen de sabbat weer in ere te herstellen? Vanuit de Sabbatstichting wordt de laatste vraag uiteraard bevestigend beantwoord. Deze stichting zet zich in voor volledig eerherstel voor de zevende dag (zaterdag), als de door God gegeven rustdag (http:// www.sabbatstichting.nl/site/).

De vragen rondom sabbat en zondag zijn niet alleen van theologische aard. Zij hebben ook alles te maken met ontwikkelingen in de samenleving. Lezers van het Reformatorisch Dagblad worden nauwgezet op de hoogte gehouden van de debatten in gemeenten binnen de biblebelt over openstelling van winkels op zondag. Een andere vraag is, hoe een overheid dient om te gaan met de religieuze rustdag van andere religies dan het christendom, wanneer die dag niet samenvalt met de zondag - de vrijdag voor de moslims en de zaterdag voor de joden?

Ondertussen worstelt onze moderne samenleving om rust te vinden en ligt in de 24-uurseconomie een burn-out altijd op de loer. 'Maar op een gege- 
ven moment gaat het mis. Als lichaam en geest nooit rust krijgen, raakt de balans verstoord. Het zou goed zijn om na te denken over hoe wij willen leven', aldus PvdA'er Gijs van Dijk (geciteerd door Channa Brunt in Marie Claire, april 2019, 48). Scherp is de analyse van filosofe Joke Hermsen: 'Steeds meer overheerst het gevoel dat de tijd op hol is geslagen of dat de tijd niet meer bij te benen is. Omdat de veranderingen zo snel gaan en niemand zich meer in staat acht zich aan die veranderingen aan te passen, krijgt men eerst het gevoel achter te lopen en vervolgens het gevoel uitgerangeerd te zijn. Om dat te voorkomen voelen de mensen zich gedwongen de veranderingen bij te houden. Hijgend lopen ze als het ware achter de tijd aan, want er is nauwelijks tijd om zich de vele veranderingen toe te eigenen. Juist deze door de tijd voortgedreven mens doet zich daardoor voor als een tijdloze mens, dat wil zeggen een mens die niet meer kan verwijlen bij de tijd. Want we willen wel onthaasten, rust vinden, consuminderen en vertragen, maar het lijkt ons niet echt te lukken' (Stil de tijd. Pleidooi voor een langzame toekomst, Amsterdam, Antwerpen, 201012, 19-20). De woorden 'zondag' en 'sabbat' komen we niet tegen in haar pleidooi, maar het lijkt erop dat via de achterdeur de kern waarom het gaat in het vierde gebod, weer wordt binnengehaald. Zo bepleit Marli Huijer een steeds terugkerende accudag die een mens nodig heeft om het vol te kunnen houden. Zij heeft wel oog voor de betekenis van sabbat en zondag voor een moderne samenleving (Ritme. Op zoek naar een terugkerende tijd, Amsterdam, 2015, 94-95).

Recent zijn twee Engelstalige studies verschenen over de theologie en praktijk van de rustdag gedurende de zeventiende eeuw in de Nederlanden. Bij de boekbesprekingen zouden deze boeken geplaatst worden in de rubriek 'kerken theologiegeschiedenis'. Casey Carmichael ( $\mathrm{PhD}$ Universiteit van Genève) presenteert zich als onafhankelijk vertaler in St. Charles, Missouri, USA. Van zijn hand verscheen in 2016 een Engelse vertaling van Johannes Coccejus' De Leer van het Verbond en het Testament van God in de serie Classic Reformed Theology. Kyle J. Dieleman is universitair docent geschiedenis aan het Trinity Christian College in Palos Heights, Illinois, USA. De auteurs doen in hun boeken geen poging om de resultaten van hun onderzoek te relateren aan bovenstaande overwegingen met betrekking tot de huidige samenleving. Dieleman onderstreept op zijn webpagina op de website van het Trinity Christian College wel het belang van zijn onderzoek voor de huidige situatie: 'This research is important for Christians who continue to value the idea of a Sabbath and for those interested in what Sunday observance might look like in contemporary Christianity' (https://www.trnty.edu/faculty/kyle-dieleman/).

De studie van Carmichael is een uitwerking van de these dat Coccejus' 
theologie van de sabbat fungeert als een venster dat zicht geeft op zijn verbondstheologie. Na de inleiding wordt in een drietal hoofdstukken de sabbat in de gereformeerde orthodoxie voor het voetlicht gebracht. Vervolgens wordt in het tweede deel in vier hoofdstukken Coccejus' theologie van de sabbat geanalyseerd. De auteur heeft gekozen voor een diachrone aanpak, zodat - in vergelijking met bijvoorbeeld Gottlob Schrenk, Gottesreich und Bund duidelijker zichtbaar wordt hoe het denken van Coccejus over de sabbat zich ontwikkeld heeft. Daar komt bij dat in deze aanpak het mogelijk is om de sociale en politieke context nadrukkelijker te betrekken bij de analyse van de bronteksten.

Carmichael biedt zijn lezers eerst een globaal overzicht van de interpretatie van de sabbat in relatie tot de zondag. Hij volgt de conclusie van Rordorf dat de christelijke zondagsrust niet bestond uit een volledig afzien van werken, maar zich beperkte tot de tijd van de eredienst. De grote wending komt ten tijde van de regering van keizer Constantijn. Eusebius is de eerste die een poging doet om de christelijke zondag en de joodse sabbat theologisch met elkaar te verbinden en de sabbat over te dragen op de zondag. $\mathrm{Na}$ een beschrijving van de ontwikkelingen in de Middeleeuwen worden Luther, Calvijn en Bullinger voor het voetlicht gehaald. De vergelijking van de positie van Calvijn en Bullinger leidt tot de interessante observatie dat Bullinger veel meer geneigd is om gedetailleerde, ethische instructies te geven. Dieleman gaat nog veel uitvoeriger in op Calvijn en vergelijkt nauwkeurig de behandeling van het vierde gebod in de Institutie en de preken over Deuteronomium. Vooral in de tweede preek onderstreept Calvijn het rusten van werken op de rustdag. Het accent ligt echter op de geestelijke rust, waarbij de gelovigen afzien van hun eigen werken om God te laten werken in hun leven. 'Calvin's concern for work on the Sabbath is relatively, if not surprisingly, relaxed. Calvin is concerned about work on the Sabbath but mainly because it threatens Christian's ability to focus on God and God's work in them' (Dieleman, 73). In beide boeken is sprake van een goede balans tussen de eigen analyse en interpretatie van de bronteksten en de secundaire literatuur die bij het onderzoek wordt betrokken. Niettemin valt het op dat geen van beide auteurs de monografie van Jürgen Kaiser - nota bene eveneens uitgegeven bij Vandenhoeck \& Ruprecht - ter hand hebben genomen (Ruhe der Seele und Siegel der Hoffnung. Die Deutungen des Sabbats in der Reformation [Forschungen zur Kirchen- und Dogmengeschichte], 1996).

De context waarin Coccejus theologiseerde wordt bepaald door het Engelse puritanisme en de ontwikkelingen in de Nederlanden na de nationale Synode van Dordrecht (1618-1619). In de Westminster Confessie is de puriteinse leer van de sabbat vastgelegd: 'Zoals het in de natuurwet ligt dat, in het 
algemeen, een behoorlijke hoeveelheid tijd gereserveerd moet worden voor de verering van God, zo heeft Hij in zijn Woord door een stellig, zedelijk en altijd geldend gebod dat alle mensen in alle eeuwen bindt, één dag uit de zeven in het bijzonder als sabbat aangewezen, die dan ook aan Hem moet worden geheiligd. Dat was van het begin van de wereld tot aan de opstanding van Christus de laatste dag van de week. Maar vanaf Christus' opstanding is hij veranderd in de eerste dag van de week. Deze wordt in de Schrift de Dag des Heren genoemd, en moet als de Christelijke sabbat onderhouden worden tot aan het einde van de wereld' (hoofdstuk 21, par. 8). Nauwkeurig wordt in het volgende artikel aangegeven hoe de dag moet worden ingevuld. De theoloog Amesius beargumenteert in zijn Marrow of Theology op grond van de aanwijzingen voor het sabbatsbrandoffer in Nummeri 28:9-10, dat op de sabbat zowel voor als na de middag een eredienst gehouden moet worden.

Coccejus deelde met theologen als Gomarus en Rivetus de overtuiging dat de sabbat niet reeds bij de schepping was ingesteld 'together with a perpetual, moral one day in seven principle', maar pas bij de wetgeving op Sinaï. 'The new, distinctive feature of his articulation of the Sabbath is that he situates it in a convenant-theological context, which leads to a more pronounced focus on spiritual, typological, and christological interpretation of the fourth commandment' (108). Zowel in de systematische doordenking van de sabbat, als in de polemische geschriften komen we onder de indruk van Coccejus' denkkracht. De focus ligt bij hem niet op een strikt verbod op werken en recreatie, maar op de instandhouding van de openbare eredienst. Zijn tegenstanders verweten hem dat hij noodzaak van een wekelijkse dag voor de eredienst loochende - hetgeen beslist niet het geval is. Carmichael's diachrone analyse van Coccejus' theologie laat overtuigend zien hoe de felle discussies die gevoerd zijn over het vierde gebod van invloed zijn geweest op de ontwikkeling van zijn verbondstheologie.

De polemiek blijft niet beperkt tot de academie en het wordt duidelijk hoe nauw theologie en vormgeving van het christelijke leven met elkaar verbonden zijn. G.D.J. Schotel geeft een sprankelende beschrijving: 'Terwijl de kweekelingen der utrechtse hoogeschool de gevoelens hunner leermeesters voortplantten en overdreven, deden zulks de kweeklingen der leidsche die van de hunne. Volgens hun oordeel was het genoeg dat men den kerkdienst waarnam; overigens kon men den dag zoo doorbrengen als men verkoos; en terwijl de Voetianen zich in hunne binnenkamers opsloten, om den Heere psalmen te zingen en te loven, zaten de Coccejanen in kroegen bier te drinken, reden en rosten, sierlijk uitgedoscht, over wegen en straten' (De openbare eeredienst der Nederl. Hervormde kerk in de zestiende, zeventiende en achttiende eeuw, Haarlem, 1870, 217). 
Wie na lezing van het boek over Coccejus de studie van Dieleman ter hand neemt, verbaast zich erover dat Coccejus slechts eenmaal terloops wordt genoemd: 'Compared to Voetius, Cocceius was a more liberal theologian who believed in the complexity of Scripture and the importance of careful biblical interpretation and theology' (110). Dieleman wil niet alleen de theologie achter de onderhouding van de sabbat in kaart brengen, maar ook zicht krijgen op de wijze waarop de sabbat gepraktiseerd is in de zeventiende eeuw. Naast de onvermijdelijke overlappingen, vullen beide studies elkaar dus ook op een mooie manier aan. In hoofdstuk 2 schetst Dieleman de achtergrond van de opvattingen omtrent de sabbat in de Republiek aan de hand van de geschriften die geschreven zijn in de vluchtelingengemeenten te Londen en Emden, en de Heidelbergse Catechismus, samen met de Catechismus maior en minor van de hand van Zacharias Ursinus. Tegen deze achtergrond is het Dieleman er vooral om te doen vanuit de bronnen 'to illuminate how people incorporated Sunday experiences into their religious lives, taking into account the role theology and religious authority played in such experiences' (30). De acta van de provinciale synodes, classicale acta en de kerkenraadsnotulen van de stad Kampen zijn voor dit onderzoek onderzocht. Twee dingen vallen op. Ten eerste worden de zes artikelen die opgesteld zijn tijdens de $164^{\mathrm{e}}$ vergadering van de nationale synode niet besproken (zie daarentegen Carmichael, 81-82). Ten tweede is Dieleman al te stellig, wanneer hij beweert dat 'no scholars have examined Dutch consistory records with a particular eye on Sabbath observance' (19). Ik volsta hier met het noemen van Fred van Lieburg, Een eiland na de Reformatie. Schouwen-Duiveland 1572-1700, Amsterdam, 2011, 270-282.

De analyse van de provinciale acta makt duidelijk dat de onderhouding van de sabbat de gereformeerde kerk in staat stelde zich duidelijk te onderscheiden van rooms-katholieken en dopers. Voor de gezagsdragers was orde in de samenleving van het grootste belang. Nergens bevatten de acta een hint dat de sabbat ook op een andere dag dan de zondag gevierd zou kunnen worden. Calvijn kon in dit verband schrijven: 'Toch hang ik ook niet zo aan het getal "zeven" dat ik de kerk strikt daaraan zou willen binden, en ik zal gemeenten die een andere vaste dag voor hun samenkomsten aanhouden daarom niet veroordelen, als er maar geen bijgelovigheid aan te pas komt' (Institutie 2.8.34; vert. C. de Niet).

Bij de uitwerking van de analyse van de classicale acta zouden grafieken en tabellen goede diensten kunnen bewijzen (zie vooral 175-176). Voor de classes vormde de eredienst het belangrijkste aandachtspunt van de sabbat. Dieleman wil echter de gewone gelovigen zo dicht mogelijk op de huid komen en met het oog daarop heeft hij de notulen van het consistorie van Kampen gedurende de jaren 1618-1649 onderzocht. In het oog springt de zorg voor 
het bijwonen van de zondagse middagdienst. 'Religious authorities demanded proper Sabbath devotion even if Dutch congregants more frequently preferred desecration' (223). Een van de belangrijkste conclusies van Dielemans onderzoek is, dat er in de Republiek al sprake is van een strikte onderhouding van de sabbat voordat de puriteinse invloed zich nadrukkelijker laat gelden: 'While English Puritanism certainly influenced a theological tendency towards Sabbatarianism in the Dutch tradition, a strict, sabbatarian Sunday observance was the goal of Dutch church authorities and the demand for such Sunday observance was quite inherent within the Dutch Reformed Church' (231). Daarnaast blijkt de verhouding tussen theologie en de religieuze praktijk uitermate gecompliceerd te zijn.

In een tijd waarin alle kaarten gezet worden op klimaat en milieu hebben Carmichael en Dieleman hun onderzoeken met betrekking tot de sabbat gepubliceerd. We vinden het heel normaal dat de overheid maatregelen neemt om de dreigende vernietiging van ons leefmilieu tegen te gaan. Maar heeft diezelfde overheid niet het recht te spreken over het temporele milieu? Ik bedoel dan het principe van één-plus-zes dagen. Een boeiend gezichtspunt heeft Hans Küng naar voren gebracht: 'Nadat het ecologische evenwicht al uit de voegen is geraakt, zou op deze manier (te weten bij het verlies van de gemeenschappelijke rustdag) het humane evenwicht van onze maatschappij ten diepste verstoord worden ... Zonder synchrone tijden nog meer versplinterde families, gebroken gemeenschappen, anoniem geworden samenleving' (geciteerd naar C.B. Posthumus Meyjes, Een dag van staken. Zuinig zijn op de zondag, Zoetermeer, 1995, 93). Historisch onderzoek maakt duidelijk dat het niet gemakkelijk is goed om te gaan met de vrijheid van de zondag als vier- en rustdag. Maar het berokkent ons mens-zijn grote schade als we niet zouden waken over de rijkdom van de rustdag. Zowel de joodse sabbat, als de christelijke zondag is bestemd voor het eren van God, mens en dier. Eerste voorwaarde voor dat eren is: de tijd nemen. En dat betekent: zuinig zijn op de zondag! 